\title{
The Effects of Incorporation of Banana Pseudostem Flour at Different Proportions on the Sensory Properties, Proximate, and Mineral Composition and Microbial Quality of Baked Brownies
}

\author{
Marivel B. Go ${ }^{1, *}$, Rodolfo Jr. A. Golbin², Severina P. Velos ${ }^{2}$, Jonita V. Literatus ${ }^{3}$, \\ Meriam M. Sambrana ${ }^{4}$, Jeem Clyde Baird \\ ${ }^{1}$ College of Technology, Cebu Technological University, Moalboal Campus, Moalboal, Cebu 6032, Philippines \\ ${ }^{2}$ Graduate School Department, Cebu Technological University, Moalboal Campus, Moalboal, Cebu 6032, Philippines \\ ${ }^{3}$ College of Education, Cebu Technological University, San Francisco Campus, San Francisco, Cebu 6050, Philippines \\ ${ }^{4}$ College of Education, Cebu Technological University, Moalboal Campus, Moalboal, Cebu 6032, Philippines \\ ${ }^{5}$ College of Arts and Sciences, Cebu Technological University, Moalboal Campus, Moalboal, Cebu 6032, Philippines
}

Received September 18, 2021; Revised November 9, 2021; Accepted November 28, 2021

\section{Cite This Paper in the following Citation Styles}

(a): [1] Marivel B. Go, Rodolfo Jr. A. Golbin, Severina P. Velos, Jonita V. Literatus, Meriam M. Sambrana, Jeem Clyde Baird, "The Effects of Incorporation of Banana Pseudostem Flour at Different Proportions on the Sensory Properties, Proximate, and Mineral Composition and Microbial Quality of Baked Brownies," Food Science and Technology, Vol. 9, No. 4, pp. 87 - 95, 2021. DOI: 10.13189/fst.2021.090403.

(b): Marivel B. Go, Rodolfo Jr. A. Golbin, Severina P. Velos, Jonita V. Literatus, Meriam M. Sambrana, Jeem Clyde Baird (2021). The Effects of Incorporation of Banana Pseudostem Flour at Different Proportions on the Sensory Properties, Proximate, and Mineral Composition and Microbial Quality of Baked Brownies. Food Science and Technology, 9(4), 87 - 95. DOI: 10.13189/fst.2021.090403.

Copyright $\odot 2021$ by authors, all rights reserved. Authors agree that this article remains permanently open access under the terms of the Creative Commons Attribution License 4.0 International License

\begin{abstract}
This study assessed the effects of incorporating banana pseudostem flour (BPSF) into all-purpose flour (APF) in five treatments, T0 (100\% APF), $\mathrm{T} 1(15 \%), \mathrm{T} 2(30 \%), \mathrm{T} 3(45 \%)$ and $\mathrm{T} 4(60 \%)$ on the sensory and chemical properties based on proximate composition, mineral \& microbial contents of baked brownies. This experimental study used a crossover design to gather data from 322 experts and consumers, and data were analyzed through SPSS. Findings revealed that the banana-like flavor was slightly noticeable in all treatments with BPSF. T0, T1 \& T2 were dark brown while T3 \& T4 were brown, all with a slightly noticeable banana-like odor and slightly fine texture except $\mathrm{T} 3$. The respondents rated all the brownies' sensory attributes as liked very much. Statistically, significant $(\mathrm{P}<0.05) \quad$ differences existed between treatments in each of sensory attributes and based on general acceptability, T1 (15\% BPSF) emerged as the most acceptable formulation. The moisture $(15.9-13.3$
\end{abstract}

$\mathrm{g} / 100 \mathrm{~g})$, protein $(7.9-5.76 \mathrm{~g} / 100)$, and crude fat (19.8 $-17.1 \mathrm{~g} / 100 \mathrm{~g}$ ) contents decreased as the level of BPSF increased. The values of carbohydrates (55.1 - 60.8 $\mathrm{g} / 100 \mathrm{~g})$, crude ash $(1.65-3.02 \mathrm{~g} / 100 \mathrm{~g})$, and total dietary fiber $(3.92-7.17 \mathrm{~g} / 100 \mathrm{~g})$ increased as the amount of BPSF flour increased. A similar trend was shown for the mineral contents: magnesium, calcium and sodium except for potassium, as BPSF content increased, values of such minerals increased as well. The formulated brownies were safe for consumption as all microbial parameters conformed to the standard limits. Hence, BPSF is a potential ingredient for producing nutritious pastry products.

Keywords Banana By-Products, Physical Evaluation, Chemical Analysis, Pastries, Flour 


\section{Introduction}

Banana is the world's second most-produced fruit in volume, for about $16 \%$ of the global fruit supply [1]. They are also abundant in the Philippines, the world's third-largest banana producer [2]. Therefore, every year after harvesting, many bare pseudostems are burned or cut and left behind as waste worldwide. Every year, about a hectare of banana can produce 220 tons of biomass waste [3], which can contaminate water sources and harm the ecosystem and the health of living microorganisms [4], [5]. However, banana pseudostem core can be consumed [6]. It can be used as a food source or ingredient; for example, it is eaten as a vegetable in Southeast Asia and Indo-Malesian Region [7], traditionally utilized as a food ingredient in Indian cuisines [1], and used to make candies and pickles [8], [9].

The consumption of banana pseudostem has numerous health benefits. It has high fiber content, which aids in weight loss [10-12]. It's also suitable for people with diabetes because it has a low glycemic index and a lot of nutritional fiber [4], [11], [12], and antioxidant [13], with [14] pointing out that consuming a lot of dietary fiber is beneficial to human health. It is also high in potassium, essential for muscular function, including cardiac muscle function, and aids in preventing high blood pressure and maintaining body fluid [15], [16]. Moreover, the banana pseudostem contains a significant amount of vitamin B6, producing hemoglobin and insulin, thus improving the body's ability to fight infection [17], [18]. It is also a diuretic, which aids in the detoxification of the body. Its juice is used to prevent and treat kidney stones [14].

Yet, banana pseudostem core is mostly composed of 90\% moisture, making it impossible to be stored for a long time [6]. It undergoes enzymatic reaction, turning to brown, affecting banana pseudostem-made items' sensory assessment and economic value. Hence, it needs to be processed to improve its nutritional and sensory qualities [19]. Also, it is the plant's second most abundant source of starch, making it a good source of food or has the potential to be processed into flour [4], [6], [9], [20-23], which could be used in a variety of baked goods, soups, and other dishes [8].

Processing banana pseudostem into flour can improve their shelf life [20], and the use of such as a partial replacement for wheat flour can increase dietary fiber consumption. It also improves the nutritional value of white bread and some essential macro and micro minerals [21], and other pastry products like brownies, described as food with less balanced nutrients and a lower food value that the body can use [24]. Hence incorporating BPSF in its production improves its nutritional value.

Few investigations dealt with making banana pseudostem into flour [4], [20], [21], and pastry products such as wheat bread [20], food bar [25], and biscuits [23]. The limited research on utilizing BPS in food production encourages the researchers to focus on such areas, which will eventually pave its way to being popular in the market.

Recently, studies on using BPS focused on making and assessing banana pseudostem flour like the study of Ho et al. [21] and Yuliatmoko [25]. Other studies dealt with producing pastry products, e.g., wheat bread [20], food bar [25], and biscuits [23]. Due to limited research on using BPS in food production, researchers felt the need to concentrate on this field. This study is vital as it informs the community and inspires them to consider alternative food ingredients that are locally available and ultimately benefit them and the environment. This will also tell them about the advantages of using banana pseudostem as a food source, particularly in times of food scarcity, such as the pandemic situation that we are currently experiencing, in which many people are jobless and hungry due to a lack of food supplies.

Thus, this study assesses the effects of incorporating banana pseudostem flour in five treatments: $0 \%$ (control), $15 \%, 30 \%, 45 \% \& 60 \%$ on the sensory properties of baked brownies based on descriptive and acceptability, its proximate mineral composition, \& microbial quality.

\section{Materials and Methods}

\subsection{Raw Materials}

Fresh banana pseudostem (Musa balbisiana) were collected from the Municipality of Moalboal. Other ingredients such as eggs, unsalted butter, vanilla, chocolate powder, chocolate chips, all-purpose flour, baking powder, brown sugar, granulated sugar, iodized, and salt were purchased in the local market.

\subsection{Preparation of Banana Pseudostem Flour}

The procedure of preparing the banana pseudostem flour is adopted from [4], [6], [9], [23]. The banana pseudostem were washed, and the outer sheath is removed to reveal the core. The core was cleaned, sliced into small pieces, and soaked in a $0.2 \%$ potassium meta bisulfate (KMS) concentration solution for 10 minutes to control enzymatic browning. They were dried using an electric oven at $120^{\circ} \mathrm{C}$, flipping every 20 minutes until no traces of water left. The dried samples were ground into flour using an electric pulverizer and then sieved. The $250 \mathrm{~g}$ of banana pseudostem flour is separated and then packed into clean airtight plastic and stored in a cool place for laboratory analysis. The remaining flour is mixed with all-purpose flour for the formulations of brownies. The flours' ratios in brownies' five formulations are shown in Table 1. 
Table 1. BPSF and APF ratios in five treatments of baked brownies

\begin{tabular}{|c|c|c|c|c|c|}
\hline $\begin{array}{c}\text { Percentage of } \\
\text { Flour Blends }\end{array}$ & T0 & T1 & T2 & T3 & T4 \\
\hline BPS Flour & $0 \%$ & $15 \%$ & $30 \%$ & $45 \%$ & $60 \%$ \\
\hline $\begin{array}{c}\text { All-purpose } \\
\text { flour }\end{array}$ & $100 \%$ & $85 \%$ & $70 \%$ & $65 \%$ & $40 \%$ \\
\hline
\end{tabular}

The procedure in the formulation of brownies was adopted from the study of [27].

There are five treatments of brownies (Table 1) prepared. All-purpose flour was substituted in 15\%, 30\%, $45 \%, 60 \%$, and $100 \%$ all-purpose flour served as a control. The oven was preheated to $350^{\circ} \mathrm{F}$. Butter was creamed with the sugar, salt, and vanilla in a mixer for 2 minutes on medium speed in preparing the batter. The eggs were added and beaten for another 3 minutes at a medium speed. The banana pseudostem flour (BPSF), chocolate powder, and baking powder were added and mixed at a medium speed until completely incorporated. The batter was then spread into five aluminum pans (11- 3/4 "L × 9-3/8 "W' 2-5/16 "H), lightly coated with butter, labeled with the appropriate number representing the brownies treatment (Table 1). Brownies were then baked in a conventional oven at $350^{\circ} \mathrm{F}$ for $20-30$ minutes. Each pan was tested with a toothpick to ensure that they were cooked before removing. The pan of brownies was left to cool at room temperature and then cut into 25 pieces.

\subsection{Laboratory Analysis}

The compositions of the five treatments of brownies incorporated with BPSF and APF in different ratios were brought to FAST Laboratories in Cebu City, Philippines, for the analyses of Proximate Composition. The different parameters include moisture, crude protein, crude fat, carbohydrates, crude ash, and dietary fiber using the method of Air Oven Drying-Gravimetry, Kjeldahl, Mojonnier Extraction, by calculation, Gravimetric, and Enzymatic-Gravimetry, respectively. For minerals, the Flame AES and Flame AAS were used to analyzed Sodium, Calcium, Magnesium, and Potassium. Concerning the microbial quality of brownies, the Aerobic Plate Count, E coli, S. aureus count, Yeast, and Mold Count were determined using Pour plate, IMVIC, and Spread Plate Method. Such procedures were based on the official methods of analysis of AOAC International, $19^{\text {Th }}$ ed. 2012, AOCS standard procedure Ba 6a-05 \& Shimadzu manual.

\subsection{Sensory Analysis}

This study employed a crossover design, adopted from [28], a repeated measurements design that each participant received different treatments of the formulated product during periods. The said participants involved in this study were the ten trained panelists and 322 consumers in different age groups and gender identified by using the
95\% confidence level and $+5 \%$ precision and selected through the quota sampling technique described by [29]. These participants rated the sensory properties of the formulated products based on descriptive and acceptability.

The formulations of brownies containing banana pseudostem flour were experimental, and the formulation with $100 \%$ all-purpose flour served as the control. The testing of the products was done after a day of the formulation of brownies. After tasting every treatment of the products, the participants need to drink water to remove the effect of every treatment and cannot influence the rating.

A survey questionnaire was used to measure the sensory properties and acceptance of the formulated products. The descriptive analysis comprises a 5- point scale describing the color, odor, flavor, and texture of the products. The acceptability analysis used the 9-point hedonic scale with 1- described as extremely dislike and 9-extreme like to assess the same attributes of the products as described by [30].

\subsection{Statistical Analysis}

Data obtained were consolidated and transferred to MS Excel to tabulate significant differences among treatments were analyzed through one-way ANOVA with repeated measures.

\section{Results and Discussions}

\subsection{Effects of Incorporating BPSF on Brownies' Descriptive Sensory Properties}

In this study, the flavor is described based on how noticeable is the banana in the baked brownies. As seen in table 2, all treatments with BPSF (T1-T4) obtained a range of mean scores from 3.40 to 3.93 , described as noticeable banana flavor, the least mean score (1.67) equivalent to not noticeable was obtained by the control formulation. The results showed that incorporating BPSF with $15 \%$ - 60\% (T1 to T4) provides a distinct banana flavor compared to the control. The raters probably identified such flavors among the five treatments since, at the onset, they were aware of the aroma of the BPSF that contributed to their perception of the brownies' flavor.

Color is an important sensory attribute that influences the impression of quality by consumers [31]. The results show that the highest mean (4.74) was observed in the control formulation, and the least was seen in T3 $(45 \%$ BPSF). A trend was also noted that as the BPSF concentration increased, the color's mean scores decreased, indicating the difference in color among formulations. Further, the formulations with $15 \%$ to $30 \%$ BPSF were observed to have the same color as the control formulation 
described as dark brown. The formulations (T3 \& T4 with $45 \%$ \& $60 \%$ BPSF) obtained a brown color description. The result implies that incorporating BPSF from $45 \%$ may decrease the color intensity of the product. Harahap [32] pointed out that dark chocolate is an essential component in making brownies, increasing the color and giving the sweet taste besides sugar.

Odor is suspected that chemical reactions produced a particular aroma of the banana pseudostem flour [33]. The highest mean (4.10) was observed in T1 (15\% BPSF; 85\% $\mathrm{APF}$ ), followed by $\mathrm{T} 0$, control. It was also noted that there is a decrease in mean values as the amount of BPSF increases, though all treatments have the same descriptive rating of slightly noticeable BPS odor. The results appeared to be contrasting since even in the control treatment, without BPSF, the raters slightly perceived the banana pseudostem odor, similar to the other treatment with BPSF. This means that incorporating BPSF with other ingredients in brownies formulations resulted in the difficulty of perceiving the distinct BPS odor among the treatments; thus, they perceived all treatments to have a similar odor.

Textural characteristics of baked products that are pleasing to consumers are essential to succeed in the marketplace. Quality control and product development can both benefit from assessing the tactile qualities of baked items. The results show that the highest mean (3.39) was observed in the control formulation, and the least was seen in T3 (45\% BPSF). A similar result was obtained by other formulations T1 (15\% BPSF), T2 (30\% BPSF), and $\mathrm{T} 4(60 \%$ BPSF). The different treatments of brownies showed a slightly fine texture, the same with the control formulation except for T3 described as slightly coarse. In addition, a trend was observed that generally, as the amount of BPSF increases, the rating mean scores of the formulations decrease.

\subsection{Effects of BPSF on the Acceptability of Brownies Formulations Based on Sensory Attributes}

The mean scores of the sensory properties' acceptability in five brownies' treatments based on color, odor, texture, and flavor are presented in Table 3, including the differences among treatments per attribute using the ANOVA test. The results revealed that the five treatments significantly $(p<0.05)$ differ in the brownies' flavor, color, odor, and texture attributes.

As shown in Table 3, the flavor of the control formulation, without BPSF, got significantly $(\mathrm{p}<0.05)$ the lowest score described as moderately acceptable while the other treatments ( $\mathrm{T} 1$ to $\mathrm{T} 4$ ) obtained mean scores equivalent to Like very much. Significant differences existed among treatments. T4 obtained the highest mean, followed by T3. Results appeared that those treatments containing BPSF got significantly $(\mathrm{p}<0.05)$ higher scores and were more acceptable than the control formulation. It implies further that the inclusion of BPSF in brownies from $15 \%$ to $60 \%$, which provided a prominent banana-like flavor of brownies, has probably enhanced the flavor of baked brownies and hence, got significantly higher scores than the control one.

Concerning color, the lowest score was observed in T2, which was significantly $(p<0.05)$ different from the other four treatments. Similarly, T0, the control, got the second-lowest score and was significantly $(\mathrm{p}<.05)$ different from the rest of the treatments, while T4 (8.52) was not comparable with T3 (8.46) and T5 (8.54). Also, a trend can be observed that generally, as the amount of BPSF increases, the ratings of color acceptability significantly increase as well. The dark brown color of the formulations (T3, T4, \& T5), with BPS flour, may be attributed to the light brown color of BPS flour compared to the control with white flour described as brown was significantly liked by the participants.

Table 2. Descriptive properties of brownies incorporated with BPSF in different proportions

\begin{tabular}{|c|c|c|c|c|c|c|c|c|}
\hline & \multicolumn{2}{|c|}{ Flavor } & \multicolumn{2}{|c|}{ Color } & \multicolumn{2}{|c|}{ Odor } & \multicolumn{2}{|c|}{ Texture } \\
\hline & Mean & SD & Mean & SD & Mean & SD & Mean & SD \\
\hline T0 & 4.15 & 1.1 & 4.74 & 0.85 & 4.09 & 1.13 & 3.39 & 1.31 \\
\hline $\mathrm{T} 1$ & 3.93 & 1.3 & 4.45 & 0.81 & 4.1 & 1.15 & 3.24 & 1.28 \\
\hline $\mathrm{T} 2$ & 3.47 & 1.66 & 4.26 & 0.67 & 3.87 & 1.4 & 2.74 & 1.24 \\
\hline $\mathrm{T} 3$ & 3.4 & 1.72 & 3.92 & 0.76 & 3.73 & 1.47 & 2.55 & 1.23 \\
\hline $\mathrm{T} 4$ & 3.8 & 1.47 & 3.97 & 0.73 & 3.86 & 1.36 & 2.74 & 1.16 \\
\hline \multicolumn{2}{|c|}{ Legend: Scale } & \multicolumn{3}{|c|}{ Flavor and Odor (Banana-like) } & & \multicolumn{3}{|c|}{ Texture } \\
\hline \multicolumn{2}{|c|}{$\begin{array}{c}4.2-5.00 \\
3.4-4.19 \\
2.60-3.39 \\
1.80-2.59 \\
1.00-1.79\end{array}$} & \multicolumn{2}{|c|}{$\begin{array}{l}\text { Very Noticeable } \\
\text { Noticeable } \\
\text { Moderately Noticeable } \\
\text { Slightly Noticeable } \\
\text { Not Noticeable }\end{array}$} & \multicolumn{2}{|c|}{$\begin{array}{l}\text { Dark brown } \\
\text { Brown } \\
\text { Light brown } \\
\text { Natural brown } \\
\text { Cream }\end{array}$} & \multicolumn{3}{|c|}{$\begin{array}{l}\text { Very fine } \\
\text { Moderately fine } \\
\text { Slightly fine } \\
\text { Slightly coarse } \\
\text { Coarse }\end{array}$} \\
\hline
\end{tabular}


Table 3. Results of acceptability differences on the five brownies formulations using ANOVA

\begin{tabular}{|c|c|c|c|c|c|c|c|c|c|c|c|}
\hline & \multicolumn{2}{|c|}{ Flavor } & \multicolumn{2}{|c|}{ Color } & \multicolumn{2}{|c|}{ Odor } & \multicolumn{2}{|c|}{ Texture } & \multicolumn{2}{|c|}{ General Acceptability } & \multirow{2}{*}{ P-Value } \\
\hline Treatment & Mean & SD & Mean & SD & Mean & SD & Mean & SD & Mean & SD & \\
\hline T0 & $7.97^{\mathrm{a}}$ & 0.87 & $8.30^{\mathrm{a}}$ & 0.76 & $8.02^{\mathrm{a}}$ & 0.91 & $8.19^{\mathrm{a}}$ & 0.83 & $8.3^{\mathrm{a}}$ & 0.77 & \multirow{5}{*}{$0.000^{*}$} \\
\hline $\mathrm{T} 1$ & $8.18^{\mathrm{b}}$ & 0.84 & $8.25^{\mathrm{b}}$ & 0.79 & $8.11^{\mathrm{a}}$ & 0.98 & $8.21^{\mathrm{a}}$ & 0.82 & $8.45^{\mathrm{b}}$ & 0.75 & \\
\hline $\mathrm{T} 2$ & $8.43^{\mathrm{c}}$ & 0.76 & $8.46^{\mathrm{C}}$ & 0.77 & $8.34^{\mathrm{b}}$ & 0.84 & $8.30^{\mathrm{ac}}$ & 0.88 & $8.42^{\mathrm{c}}$ & 0.71 & \\
\hline $\mathrm{T} 3$ & $8.55^{\mathrm{d}}$ & 0.77 & $8.52^{\mathrm{cd}}$ & 0.78 & $8.40^{\mathrm{b}}$ & 0.94 & $8.45^{\mathrm{b}}$ & 0.86 & $8.2^{\mathrm{d}}$ & 0.80 & \\
\hline $\mathrm{T} 4$ & $8.45^{\mathrm{c}}$ & 0.80 & $8.54^{\mathrm{d}}$ & 0.79 & $8.42^{\mathrm{b}}$ & 0.95 & $8.45^{\mathrm{bc}}$ & 0.87 & $8.19^{\mathrm{c}}$ & 0.77 & \\
\hline Legend : & \multicolumn{2}{|c|}{$\begin{array}{c}\text { Scale } \\
8.5-9.0 \\
7.5-8.49 \\
6.5-7.49 \\
5.5-6.49 \\
4.5-5.49 \\
\end{array}$} & \multicolumn{3}{|c|}{$\begin{array}{c}\text { Description } \\
\text { Like extremely } \\
\text { Like very much } \\
\text { Like moderately } \\
\text { Like slightly } \\
\text { Neither like nor dislike } \\
\end{array}$} & \multicolumn{2}{|c|}{$\begin{array}{c}\text { Scale } \\
3.5-4.49 \\
2.5-3.49 \\
1.5-2.49 \\
1.0-1.49\end{array}$} & \multicolumn{3}{|c|}{$\begin{array}{c}\text { Description } \\
\text { Dislike Slightly } \\
\text { Dislike moderately } \\
\text { Dislike very much } \\
\text { Dislike extremely }\end{array}$} & \\
\hline
\end{tabular}

Regarding odor acceptability, the least mean result (8.02) was observed in the control (T0), which is significantly $(p<0.05)$ different from all other treatments with BPSF. Treatments blended with BPSF from $15 \%$ to $60 \%$ which were described having a banana-like odor did not significantly differ $(p<0.05)$. Hence, it connotes that the participants liked more those brownies treatments containing BPSF than the control one.

For texture acceptability, T0, control got the least mean value (8.19) and not comparable to T1 \& T2. It means no significant differences existed in the flavor acceptability rating of those 3 formulations. However, T3 (45\% BPSF) and $\mathrm{T} 4(60 \%$ BPSF) obtained means significantly higher than the control treatment. Results indicate that though all treatments were perceived as liked very much, as shown above, the participants still prefer BPSF over the control one. The result of this study did not conform to the banana pseudostem-based- biscuits of Sangroula [23] that as the amount of pseudostem flour increases, the texture score decreased, which may be due to tougher texture and cracks on the crust.

Relating to general acceptability, all treatments were significantly $(p<0.05)$ different from each other, the highest score was seen in T1 (15\% BPSF), which is significantly different from the rest of the treatments, followed by $\mathrm{T} 2(30 \% \mathrm{BPSF})$, and the least was in T4 $(60 \%$ BPSF). Hence, the most acceptable formulation is T1 with $15 \%$ BPSF, having the highest scores in different sensory attributes. However, all brownies treatments are acceptable to the participants until $60 \%$ of BPSF inclusion.

However, comparing these results to other pastry products made from banana flour blends, a contrasting result was found with the study of [24]. They described the characteristics of biscuits made using hot air-dried banana flour and freeze-dried banana flour. The sensory score for color, texture, and overall acceptability of biscuits decreased as banana flour in the formulation increased. In addition, results obtained in the study of [29], that the Banana Pseudostem biscuits with the least banana flour content turn out to be the most acceptable compared to other formulations, which showed a significant difference from all other formulations, and the formulation with the greatest BPSF content showed the lowest score in overall acceptability.

\subsection{Effects of incorporating BPSF on the Proximate Composition of Brownies Five Formulations}

The proximate compositions of the formulated brownies in five treatments are shown in table 4, which were measured based on moisture, crude protein, crude fat, carbohydrates, crude ash, and dietary fiber.

The moisture content of the brownies ranged from 15.9 to 13.3, with the highest content observed in the control formulation, while T5 got the least moisture. As observed from the result, the higher the amount of the banana pseudostem flour in brownies treatment, the lower is the moisture content. The moisture content is responsible for the spoilage of the product; the result indicates that the inclusion of BPSF in brownies formulation may have longer shelf life than the control formulation. Such a result is similar to [21], in their study, the moisture content was $2.62 \%$ in control biscuits and $2.54 \%$ in banana pseudostem incorporated biscuits. However, it opposes the study of [34], who showed that the proximate compositions of the banana pseudostem revealed in the blended product had the highest moisture content $(6.42 \%)$, while the least was in the control $(3.33 \%)$ sample.

For protein and fat contents, the same trend as the moisture was observed in crude protein and crude fat, that as the BPSF content in the formulation increases, the amount of protein and fat decreases. T4 and T3 have a minimal difference $(0.87)$ in protein content. The same result was obtained in fat content for $\mathrm{T} 1$ and $\mathrm{T} 2$ with 0.1 difference. 
The current international Recommended Dietary Allowance (RDA) for protein is $0.8 \mathrm{~g}$ per $\mathrm{kg}$ of body weight regardless of age. These recommendations are based on the minimum level required to maintain nitrogen balance and are not optimized for physical activity levels [35]. Based on the RDA, the consumption of brownies may supply the required nutrients to the body.

The present result is parallel to the protein trend of banana pseudostem biscuits, which showed lower content in the banana pseudostem-based products $(18.6 \%)$ than the control $(16.26 \%)$. The banana pseudostem product has a low protein level because wheat flour's initial protein concentration (10.2 percent) is higher than banana pseudostem flour's, affecting the overall protein content of the product [4]. In addition, they also confirmed that the fat content of banana pseudostem incorporated biscuit $(18.6 \%)$ was higher than the control (16.26\%). However, an opposite trend was observed in the present study.

Regarding carbohydrates, results revealed that all treatments have significantly $(\mathrm{P}<0.05)$ different carbs composition. A trend was noted that as the level of BPSF increases, the carb content also increases since the least value was seen in the control formulation $(55.1 \%)$, and the highest is in T4 (60.8\%). The Institute of Medicine (IOM) established a carbohydrate distribution range of 45-65 percent of total calories as an acceptable macronutrient distribution range. Hence, the formulated brownies are a good source of carbohydrates.

Table 4. Chemical Compositions of Brownies

\begin{tabular}{|c|c|c|c|c|c|}
\hline $\begin{array}{c}\text { Proximate } \\
\text { Composition }\end{array}$ & T0 & T1 & T2 & T3 & T4 \\
\hline Moisture, g/100g & 15.9 & 14.9 & 14.9 & 14.5 & 13.3 \\
\hline $\begin{array}{c}\text { Crude Protein } \\
\text { (Nx6.25), g/100g }\end{array}$ & 7.9 & 6.85 & 5.98 & 5.62 & 5.76 \\
\hline Crude Fat, g/100g & 19.8 & 18.5 & 18.6 & 17.8 & 17.1 \\
\hline $\begin{array}{c}\text { Carbohydrates, } \\
\text { g/100g }\end{array}$ & 55.1 & 57.7 & 58.2 & 59.4 & 60.8 \\
\hline Crude Ash, g/100g & 1.65 & 2.05 & 2.31 & 2.67 & 3.02 \\
\hline $\begin{array}{c}\text { Total Dietary Fiber } \\
\text { g/100g }\end{array}$ & 3.92 & 6.05 & 6.14 & 6.54 & 7.17 \\
\hline
\end{tabular}

For fiber content, the increasing values are notable in the result (Table 4). It indicates that the fiber contents of brownies with BPSF have higher values than the control formulation. The banana pseudostem as the best source of fiber [4],[10] has contributed such evident results. In addition, BPSF was reported to be rich in non-starch polysaccharides or dietary fibers, including cellulose, hemicellulose, and lignin [36]. Thus, BPS-based brownies are a good source of fiber which is beneficial to human health. Comparing the findings obtained in the study of [37], the Chemical characteristic of steamed pumpkin brownies premix flour showed similar results to the present study. The same trends were observed in moisture protein, fat, and carbohydrates contents.

\subsection{Effects of Incorporating BPSF on Mineral Content of Brownies Five Formulations}

The mineral composition of the brownies with the pseudostem flour and their different treatments are shown in Table 5, with the following parameters: sodium, calcium, potassium, and magnesium.

Table 5. Mineral Content of Brownies

\begin{tabular}{|c|c|c|c|c|c|}
\hline $\begin{array}{c}\text { Proximate } \\
\text { Composition }\end{array}$ & T0 & T1 & T2 & T3 & T4 \\
\hline $\begin{array}{c}\text { Magnesiumm } \\
\mathrm{mg} / \mathrm{kg}\end{array}$ & 55.1 & 215 & 209 & 236 & 252 \\
\hline $\begin{array}{c}\text { Calcium } \\
\mathrm{mg} / \mathrm{kg}\end{array}$ & 14.2 & 17.8 & 19.5 & 36.4 & 43.3 \\
\hline $\begin{array}{c}\text { Sodium } \\
\text { g/100g }\end{array}$ & 0.097 & 0.10 & 0.11 & 0.11 & 0.12 \\
\hline $\begin{array}{c}\text { Potassium } \\
\text { g/100g }\end{array}$ & 19.8 & 0.54 & 0.59 & 0.71 & 0.77 \\
\hline
\end{tabular}

As revealed in the results, the control formulation has the least magnesium content (55.1); such amount is almost four times lesser than those formulations containing BPSF with magnesium contents ranging from $209 \mathrm{mg} / \mathrm{kg}$ to 252 $\mathrm{mg} / \mathrm{kg}$. The highest amount was seen in treatment 4 , with $100 \%$ BPSF. The recommended daily intake for magnesium is $170 \mathrm{mg}$ [38]. Hence, consuming about 670 $\mathrm{g}$ per day of brownies with BPSF will reach the recommended intake.

Concerning calcium, a similar result was observed as that of magnesium, that the lowest content $(14.2 \mathrm{mg})$ was in the control formulation and the highest was in T4 (43.3 $\mathrm{mg}$ ), with pure BPSF. An increasing trend (17.8 - $43.3 \mathrm{mg}$ ) was also noted, that as the proportion of BPSF increased, the calcium content also increased. Hence, incorporating the BPSF in brownies formulations has improved the product's calcium value from treatment 1 to 4 about $25 \%$ to $300 \%$, respectively.

The recommended daily intake of $\mathrm{Ca}$ is $450 \mathrm{mg}$; such a value is far from the obtained result of the formulated products. The amount of calcium found in the banana pseudostem flour in this study was higher than that found in banana pulp, peels, and unpeeled bananas [39-40]. Also, $\mathrm{Ca}$ was relatively high in the pseudostem due to its importance in the cell strength of the trunk that sustains the plant [41].

Regarding sodium, the result displayed the same as other elements: as the amount of BPSF increases, the sodium content has increased. The formulation without BPSF has the least sodium $(0.097 \mathrm{~g} / 100 \mathrm{~g})$ and the highest in T4 $(0.12 \mathrm{~g} / 100 \mathrm{~g})$. Hence, incorporating BPSF in food products may improve the sodium content. In the extracellular fluid of the body, sodium is the most abundant cation. It is a vital nutrient for maintaining plasma volume, acid-base balance, nerve impulse transmission, and appropriate cell function. Nearly all of the sodium consumed is absorbed during digestion in healthy people, and urine excretion is the primary method for maintaining sodium balance. 
Table 6. Microbial Component of the brownies in five treatments

\begin{tabular}{|c|c|c|c|c|c|}
\hline Proximate Composition & T0 & T1 & $\mathbf{T} 2$ & T3 & $\mathbf{T 4}$ \\
\hline $\begin{array}{l}\text { Aerobic Plate Count } \\
(\mathrm{APC})(\mathrm{CFU} / \mathrm{g})\end{array}$ & 300 & 300 & $<250^{\text {(Est) }}$ & 350 & $<250^{\text {(Est) }}$ \\
\hline E. coli & Negative & Negative & Negative & Negative & Negative \\
\hline $\begin{array}{c}\text { S.aureus Count } \\
(\mathrm{CFU} / \mathrm{g})\end{array}$ & $<10^{\text {(Est) }}$ & $<10^{\text {(Est) }}$ & $<10^{\text {(Est) }}$ & $<10^{\text {(Est) }}$ & $<10^{\text {(Est) }}$ \\
\hline $\begin{array}{c}\text { Yeast and Mold Count } \\
(\mathrm{CFU} / \mathrm{g})\end{array}$ & $20^{(\text {Est })}$ & $30^{\text {(Est) }}$ & $<10^{\text {(Est) }}$ & $40^{\text {(Est) }}$ & $<10^{\text {(Est) }}$ \\
\hline
\end{tabular}

For the potassium, the results revealed that the highest content was in the control formulation $(19.8 \mathrm{~g} / 100 \mathrm{~g})$ while all the four treatments (T1-T4) with different amounts of BPSF had a very small amount of sodium as all contained $<1 \mathrm{~g} / 100 \mathrm{~g}$. Those with hypertension and those who have excessive potassium excretion through their body fluids could benefit from potassium. Because of their role in brain transmission and muscle contraction, macro-elements including $\mathrm{Na}, \mathrm{K}, \mathrm{Ca}$, and $\mathrm{Mg}$ are vital in our daily diet [42].

\subsection{Microbial Quality of Banana Pseudostem-Based Brownies in Five Treatments}

The microbial quality of the brownies in five treatments are shown in Table 6, with the parameters aerobic plate count, E. coli, S. aureus count, and yeast and mold count. For aerobic plate count (CFU/g), it is intended to indicate a product's microorganism level. The range of values was $<250-350 \mathrm{cfu} / \mathrm{g}$, which conforms to the standard limit of $104 \mathrm{cfu} / \mathrm{g}$, based on AO No. 184 s. 2004, FDA limits for formulated products.

Moreover, E. coli is negative with S. aureus count $(\mathrm{CFU} / \mathrm{g})<10$ (Est) in all formulations. Also, the range of yeast and mold count $(\mathrm{CFU} / \mathrm{g})$ in five formulations is (10-40 cfu/g). All microbial parameter results conform to the standard limit set by FDA for processed foods, negative for E.coli, and 103 for yeast and mold. Therefore, the formulated products are considered safe for consumption.

\section{Conclusion}

The brownies with BSF up $60 \%$ were highly acceptable to the consumers based on the 9-point hedonic scale. But, the most acceptable formulation based on the general acceptability score was $\mathrm{T} 1$ which is incorporated with $15 \%$ BPSF and $85 \%$ APF. The formulated brownies contain macro and micronutrients needed by the body and safe for consumption as all microbial parameters conformed to the standard limits. Hence, banana pseudostem is a potential ingredient for producing nutritious pastry products.

\section{Acknowledgment}

The authors would like to thank Cebu Technological
University for the funds provided to support this project.

\section{REFERENCES}

[1] Mohapatra, D., Sabyasachi M., and Namrata S. "Banana and its by-product utilization: an overview." Journal of Scientific \& Industrial Research Volume 69, pp. 323-329, 2010. http://hdl.handle.net/123456789/8581

[2] Briones, R. M. "Domestic resource cost in Philippine agriculture: measuring global competitiveness of key commodities" Philippine Journal of Development, Volume 41 No. 1/2, p.157, 2014.https://econpapers.repec.org/paper /phdpjdevt/pjd_5f2014-2015_5fvol_5f_5f41-42_5fnos_5f_ 5f1-2g.htm

[3] Ahmad, T. \& Danish, M. "Prospects of banana waste utilization in wastewater treatment: A review" Journal of environmental management, Volume 206, pp. 330-348, 2018. doi.org/10.1016/j.jenvman.2017.10.061

[4] Aziz, N. A. A., Ho, L. H., Azahari, B., Bhat, R., Cheng, L. H., \& Ibrahim, M. N. M. "Chemical and functional properties of the native banana (Musa acuminatax balbisiana Colla cv. Awak) pseudostem and pseudostem tender core flours", Food Chemistry, Volume 128 No.3, pp. 748-753, 2011. doi.org/10.1016/j.foodchem.2011.03.100

[5] Alshammari, A. M., Adnan, F. M., Mustafa, H., \& Hammad, $\mathrm{N}$. "Bioethanol fuel production from rotten banana as an environmental waste management and sustainable energy", African journal of microbiology Research Volume 5 No. 6, pp. 586-598, 2011.https://doi.org/10.5897/AJMR10.231

[6] Thorat, R. L., \& Bobade, H. P. Utilization of banana pseudostem in food applications. International Journal of Agricultural Engineering, Volume 11, pp. 86-89. 2018. https://www.cabdirect.org/cabdirect/abstract/20183195936

[7] Kennedy J Bananas and people in the homeland of genus Musa: not just pretty fruit. Ethnobotany Research and Application Volume 7: pages 179-197, 2009. https://ethnobotanyjournal.org/index.php/era/article/view/3 $60 / 239$

[8] Kaddumukasa, P., Kyamuhangire, W., Muyonga, J. and Muranga, F. I. "The effect of drying methods on the quality of green banana flour" African Crop Science Conference Proc. Volume 7, pp. 1267-1271, (2005). https://www.afric abib.org/rec.php?RID=Q00045534

[9] Lakshman, R., Ambrose, D. C., \& Chelvame, D. "Studies on the quality of banana center core flour prepared by 
different drying methods" Current Agriculture Research Journal, Volume 3 No. 1, pp. 55-59, 2015. http://dx.doi.org/10.12944/CARJ.3.1.07

[10] Chandrasekaran, S.V. "Fiber of health" THE HINDU Chennai Edition, 2012. https://www.thehindu.com/news/ci ties/chennai/chen-food/chen-recipes/fibre-of-health/article 4016286.ece

[11] Kumar, K. S., Bhowmik, D., Duraivel, S., \& Umadevi, M. "Traditional and medicinal uses of banana. Journal of Pharmacognosy and Phytochemistry" Volume 1 No 3, pp. 51-63, 2012. https://www.phytojournal.com/vol1Issue3/Iss ue_sept_2012/9.1.pdf

[12] Ranjha, M. M. A. N., Irfan, S., Nadeem, M., \& Mahmood, S. "A comprehensive review on nutritional value, medicinal uses, and processing of banana", Food Reviews International, pp. 1-27, 2020. doi.org/10.1080/87559129.2 020.1725890

[13] Bhaskar, J. J., Shobha, M. S., Sambaiah, K. and Salimath, P. V. "Beneficial effects of banana (Musa sp. var. elakki bale) flower and pseudostem on hyperglycemia and advanced glycation end-products (AGEs) in streptozotocin-induced diabetic rats." Journal of Physiology Biochem, Volume 67 No. 3, pp. 415-425, 2011. doi:10.1007/s13105-011-0091-5

[14] Cpambrose, D., Lakshman, R., \& Naik, R. "Studies on the drying kinetics and quality assessment of banana pseudostem waste for effective utilization as a value-added product" International Journal of Farm Sciences, Volume 6 No.2, pp. 276-285, 2016. https://www.cabdirect.org/cabdir ect/abstract/20163168902

[15] Neog, S. R., \& Deka, C. D. "Salt substitute from banana plant (Musa Balbiciana Colla)". Journal on Chemical and Pharmaceutical Research, Volume 5 No.6, pp. 155-159, 2013.https://www.researchgate.net/profile/Dc-Deka/public ation/289017909_Salt_substitute_from_banana_plant_Mus a-_balbisiana_Colla/links/5eb17d1e45851592d6b9b466/Sa lt-substitute-from-banana-plant-Musa-balbisiana-Colla.pdf

[16] Singh, R., Kaushik, R., \& Gosewade, S. "Bananas as underutilized fruit having huge potential as raw materials for food and non-food processing industries: A brief review" The Pharma Innovation Journal, Volume 7 No.6, pp.574-580, 2018. https://www.thepharmajournal.com/arc hives/2018/vol7issue6/PartI/7-6-103-451.pdf

[17] Raju, S.K., Philomena Joy Lindsey, A. and Emilin Renitta, R. "Shelf life assessment of Banana pseudostem cutlet", International Journal of Engineering and Advanced Technology Volume 8 No. 6, pp. 210-214, 2019.

[18] Rajesh, N. "Medicinal benefits of Musa paradisiaca (banana)", International Journal of Biology, Volume 2 No. 2, pp. 51-54, 2017.

[19] Ekezie, F. G. C., Sun, D. W., Han, Z., \& Cheng, J. H. "Microwave-assisted food processing technologies for enhancing product quality and process efficiency: A review of recent developments", Trends in Food Science \& Technology Volume 67, pp. 58-69, 2017.

[20] Ho, L. H., Aziz, N. A. A., \& Azahari, B. "Physico-chemical characteristics and sensory evaluation of wheat bread partially substituted with banana (Musa acuminata X balbisiana cv. Awak) pseudostem flour" Food Chemistry
Volume 139 No. 1-4, pp. 532-539, 2013. doi.org/10.1016/j.foodchem.2013.01.039

[21] Ho, L. H., Tan, T. C., Aziz, N. A. A., \& Muhamad, N. "Physical and functional properties of banana pseudostem flour and its effect on the quality (texture and microstructure) of formulated bread" Journal of Agrobiotechnology Volume 8 No.1, pp.1-12, 2017. https://journal.unisza.edu.my/agrobiotechnology/index.php /agrobiotechnology/article/view/161

[22] Asif-Ul-Alam, S. M., Islam, M. Z., Hoque, M. M., \& Monalisa, K. "Effects of drying on the physicochemical and functional properties of green banana (Musa sapientum) flour and development of baked product", American Journal of Food Science and Technology, Volume 2 No. 4, pp.128-133, 2014. DOI:10.12691/ajfst-2-4-4

[23] Sangroula, P. "Utilization of banana pseudostem for biscuit making" Doctoral dissertation, 2018. http://202.45.146.37: 8080/jspui/handle/123456789/115

[24] Ligarnasari, I. P., Anam, C., \& Sanjaya, A. P. "Physical, chemical and sensory properties of brownies substituted with sweet potato flour (Ipomoea batatas L.) with addition of black cumin oil (Nigella sativa L.)" In IOP Conference Series: Earth and Environmental Science Volume 102 No 1, p. 012084, IOP Publishing. 2018. doi :10.1088/1755-1315/ $102 / 1 / 012084$

[25] Yuliatmoko, W., et al. "Chemical and functional properties of Cavendish Jepara 30 (Musa Cavendishii) banana pseudostem flour after blanching and soaking in sodium bisulphite solution." Pakistan Journal of Nutrition 18.10 (2019): 936-945.

[26] YULIATMOKO, WELLI. POTENSI TEPUNG EMPULUR BATANG PISANG (Musa acuminata Colla) PADA PEMBUATAN FOOD BAR ANTI DISLIPIDEMIA BERBAHAN PATI GANYONG (Canna edulis Ker.). Diss. Universitas Gadjah Mada, 2020. http://etd.repository.ugm.ac.id/penelitian/detail/187656

[27] Fleischer, A. M.” Acceptability of brownies supplemented with black bean puree by college students at Indiana State University (Doctoral dissertation, Indiana State University", 2013.https://www.proquest.com/openview/f207c8f9a97b8 $0594764 \mathrm{ca} 5 \mathrm{~d} 559 \mathrm{cdaed} / 1$ ?cbl=18750\&pq-origsite $=$ gschola

[28] Morris, C. "Impact of product name and seasonal context on the sensory evaluation of a seasonally themed beverage" Journal of Sensory Studies, Volume 33 No. 2, e12320, 2018. https://doi.org/10.1111/joss.12320

[29] Martínez-Mesa, J., González-Chica, D. A., Duquia, R. P., Bonamigo, R. R., \& Bastos, J. L. "Sampling: how to select participants in my research study" Anais brasileiros de dermatologia, Volume 91 No.3, pp. 326-330, 2016. https://doi.org/10.1590/abd1806-4841.20165254

[30] Go, M. B., Velos, S. P., Minyamin, A. V., Bagsit, R. D., \& Pableo, R.G. "Sensory Evaluation, Shelflife, and Nutritional Composition of Breadnut (Artocarpus camansi) Cookies. Tropical Technology Journal, Volume 1 No. 19, pp. 1-7, 2015. DOI 10.7603/s40934-015-0009-x

[31] Hutchings, J. B., "Color Measurements" Encyclopedia of Analytical Science. Pp.198-208, 2005. 
[32] Harahap, Definition dark chocolate. (2010).

[33] Ladamay, N. A \& SS Yuwono. "Utilization of Local Materials in Making Foodbars(Tapioca Rasio Study: Green Bean Flour and CMC Proportion)" Food Journal and Agroindustry. Vol. 2 No. 1, pp. 67-78, 2014.

[34] Steve, I. O., Temitope, O. M., \& Stephen, O. B. "Chemical, functional and sensory properties of roasted bambara groundnut (Vigna subterranean L. Verdc) and cooking banana (Musa spp., ABB genome) weaning diet", African Journal of Food Science Volume 3 No. 5, pp. 139-146, 2009. http://www.academicjournals.org/ajfs

[35] Lonnie, M., Hooker, E., Brunstrom, J. M., Corfe, B. M., Green, M. A., Watson, A. W., \& Johnstone, A. M. "Protein for life: Review of optimal protein intake, sustainable dietary sources and the effect on appetite in ageing adults", Nutrients Volume 10 No. 3, p. 360, 2018. https://doi.org/10.3390/nu10030360

[36] Cordeiro, N., Belgacem, M. N., Torres, I. C., \& Moura, J. C. V. P. "Chemical composition and pulping of banana pseudostems", Industrial Crops and Products, Volume 19, pp. 147-154, 2004. doi.org/10.1016/j.indcrop.2003.09.001

[37] Subaktilah, Y., Wahyono, A., Yudiastuti, S. O. N., \& Avianti, T. M.. "Chemical characteristic of steamed pumpkin brownies premix flour.” In IOP Conference Series: Earth and Environmental Science IOP Publishing, March
2021, Vol. 672, No. 1, p. 012054, doi:10.1088/1755-1315/ $672 / 1 / 012054$

[38] Natera, E., Trinidad, T., Valdez, D., Kawamura, H., Palad, L., \& Shiraishi, K. "Estimation of daily micronutrient intake of Filipinos", Food and nutrition bulletin Volume 23 No. 3_suppl1, pp. 222-227, 2002. doi.org/10.1177/1564826502 $0233 \mathrm{~S} 144$

[39] Selema, M. D., \& Farago, M. E. "Trace element concentrations in the fruit peels and trunks of Musa paradisiaca" Phytochemistry Volume 42 No. 6, pp. 1523-1525, 1996. doi.org/10.1016/0031-9422(96)00165-3

[40] Haslinda, W. H., Cheng, L. H., Chong, L. C., \& Aziah, A. N. "Chemical composition and physicochemical properties of green banana (Musa acuminata $\times$ balbisiana Colla cv. Awak) flour", International journal of food sciences and nutrition, Volume 60 - sup4, pp. 232-239. (2009). doi.org/10.1080/0 9637480902915525

[41] Twyford, I. T., \& Walmsley, D. "The mineral composition of the Robusta banana plant II. The concentration of mineral constituents", Plant and Soil, Volume 41 No. 3, pp. 459-470, 1974. https://www.jstor.org/stable/42932497

[42] Hendricks, K. M., \& Herbold, N. H. "Diet, activity, and other health-related behaviors in college-age women", Nutrition reviews, Volume 56 No. 3, pp. 65-75, 1998. doi.org/10.1111/j.1753-4887.1998.tb01696.x 